\title{
Efficacy and Safety of Percutaneous Radiofrequency Thermal Ablation in the Treatment of Lung Cancer Lesions
}

\author{
Eficácia e Segurança da Termoablação Percutânea por Radiofrequência no \\ Tratamento das Lesões Cancerígenas Pulmonares
}

Ana TAVARES E CASTRO'1, Sara FREITAS ${ }^{1}$, Antónia PORTILHA², Fernando ALVES ${ }^{2}$, Filipe CASEIRO-ALVES ${ }^{2}$

Acta Med Port 2015 Jan-Feb;28(1):63-69

ABSTRACT

Introduction: In this study, we reviewed a clinical series composed by all malignant lung lesions submitted to computed tomographyguided percutaneous thermal radiofrequency ablation, in our hospital, a rather recent technique that has been gaining scientific recognition.

Material and Methods: For data purposes, all radiofrequency ablation and corresponding clinical records were retrospectively analysed. A computed tomography scan was performed before and after each procedure to evaluate the tumour's features, and at a second step to assess results and complications. The frequency of local recurrence and disease progression were determined based on imaging follow-up. Kaplan-Meier analysis was used to estimate survival. Univariate analysis recognized clinical and pathological factors affecting survival. These were also tested by multivariate analysis.

Results: A total of 28 malignant lung lesions, 20 primary and 8 metastatic, from 28 patients ( $78.6 \%$ male; mean age $62 \pm 17$ years old), were submitted to computed tomography-guided radiofrequency ablation between January 2004 and July 2010. Total necrosis was achieved in $74.1 \%$ of the lesions. Immediate radiofrequency ablation-related complications were observed in half of the procedures. Among major complications, death occurred in one patient only. Median overall survival was 43.0 months for a mean 2-years follow-up. Median progression-free survival was 31.6 months. Lesion's size smaller than $35 \mathrm{~mm}$, stage III disease by the TNM classification and previous treatment attempts were significantly associated with better outcomes. Disease-related mortality was $46.4 \%$.

Discussion: This procedure proved to be efficient to treat lung cancerous lesions, with a low-rate of major complications.

Conclusions: Computed tomography-guided percutaneous radiofrequency ablation is a minimally invasive procedure that appears to be valuable in the treatment of lung cancer lesions.

Keywords: Catheter Ablation; Lung Neoplasms; Tomography, X-Ray Computed.

\section{RESUMO}

Introdução: Neste estudo foram caracterizados e avaliados todos os tumores malignos do pulmão no nosso hospital submetidos a termoablação percutânea por radiofrequência guiada por tomografia computadorizada, uma técnica relativamente recente com crescente evidência científica.

Material e Métodos: Os registos clínicos referentes a todas as termoablações percutâneas por radiofrequência realizadas na nossa instituição foram retrospectivamente analisados. Realizou-se uma tomografia computadorizada antes e depois de cada procedimento para avaliar as características do tumor e, numa segunda fase, para avaliar os resultados e complicações. A recorrência e progressão da doença foram determinados através do seguimento imagiológico. A análise Kaplan-Meier foi usada para calcular a sobrevivência. A análise univariada identificou os fatores clínicos e patológicos que afetaram a sobrevivência.

Resultados: Um total de 28 lesões pulmonares malignas, 20 carcinomas primários e oito lesões metastáticas, de 28 doentes $(78,6 \%$ do género masculino, com idade média de $62 \pm 17$ anos), foram submetidos a termoablação percutânea por radiofrequência entre janeiro de 2004 e julho de 2010. Obteve-se necrose total em $74,1 \%$ das lesões. Observaram-se complicações imediatas em metade dos procedimentos. Das principais complicações, ocorreu a morte em apenas um doente. A sobrevivência mediana global foi de 43,0 meses para uma média de dois anos de acompanhamento. A sobrevivência mediana sem progressão da doença foi de 31,6 meses. Os fatores que mostraram correlação estatisticamente significativa com melhores resultados foram: tamanho da lesão menor que $35 \mathrm{~mm}$, doença no estádio III da classificação TNM e realização de tratamentos prévios. A mortalidade por progressão da doença foi de $46,4 \%$. Discussão: Este procedimento provou ser eficaz no tratamento de lesões pulmonares cancerígenas, com uma baixa incidência de complicações graves.

Conclusões: A termoablação percutânea por radiofrequência é um procedimento minimamente invasivo, que aparenta ser vantajoso no tratamento de lesões cancerígenas do pulmão.

Palavras-chave: Ablação por Cateter; Neoplasias do Pulmão; Tomografia Computorizada.

\section{INTRODUCTION}

Lung cancer is the most commonly diagnosed malignant disease in the world and has been the primary cause of cancer related-death for several decades., ${ }^{1,2}$ The lung is also one of the most likely sites for metastatic malignant disease, especially for adenocarcinomas. ${ }^{3}$

Established treatment options include surgical resection, radiotherapy (RT), chemotherapy (CTX) or a combination of these modalities. Although surgery is not recommended for advanced disease, in the early-stage non-small cell lung cancer (NSCLC), surgical resection is still the preferred treatment. ${ }^{4}$ Unfortunately, not all patients are eligible for surgery mostly due to comorbidities, and poor cardiorespiratory function in particular, that place them at high risk for surgical procedures. These patients

1. Pulmonology Unit. Hospitais da Universidade de Coimbra. Centro Hospitalar e Universitário de Coimbra. Coimbra. Portugal.

2. Radiology Unit. Hospitais da Universidade de Coimbra. Centro Hospitalar e Universitário de Coimbra. Coimbra. Portugal.

Recebido: 02 de Junho de 2014 - Aceite: 16 de Dezembro de 2014 | Copyright @ Ordem dos Médicos 2015 
may be considered for treatment with conventional external beam RT, but this modality poses a considerable risk for radiation pneumonitis. Stereotactic RT (SRT) has also been increasingly used for the treatment of early-stage lung cancer. ${ }^{5,6}$ However, SRT is also associated with radiation pneumonitis and other complications such as rib fractures and skin rash, and has been linked with increased lengths of hospital stay. ${ }^{7}$

Image-guided percutaneous therapies have been developed as local or minimally invasive alternative treatments, trying to overcome the above referred limitations. ${ }^{8,9}$ Its use in the treatment of diverse solid malignancies, specifically hepatic, renal and bone, has had successful results and has long been accepted as a suitable therapeutic option. ${ }^{10-14}$ Among these interventional radiological procedures, radiofrequency ablation (RFA) is a recently developed technique and there is growing scientific evidence supporting its use for primary and secondary lung tumours treatment. ${ }^{15-24}$ RFA destroys lung tumours via tissue heating, which is attained by the delivery of hot thermal energy through percutaneous needles, inserted under computed tomography guidance. Immediate cell death occurs when tissue temperatures reach more than $60^{\circ} \mathrm{C} . .^{25}$ RFA can be performed under conscious sedation and the incidence of side effects is quite low. The procedure safeness partially depends on the anatomical and physiological conditions of the lung itself. A high pulmonary vascular flow and constant air exchange promptly dissipate heat from normal parenchyma and concentrate energy within the tumour, a phenomena known as 'sink effect' .26,27

RFA can be associated to other treatment modalities, namely RT, offering synergistic results. In fact, compared to RT alone, combined therapy has revealed significant improvements in local tumour control and survival rates. ${ }^{28,29}$ Despite of these advantages and promising results, RFA is still not an established technique, since there have been very few clinical trials and most oncology units have minimum experience of this procedure.

This study describes our experience in a population of patients with malignant lung tumours, mainly primary cancers, treated by RFA in a central Portuguese hospital.

\section{MATERIAL AND METHODS \\ Study Population}

Data from all patients submitted to lung RFA, between 2004 and 2010, were retrospectively collected. Patients

Table 1 - Reasons for excluding surgery as first treatment approach

\begin{tabular}{lc}
\hline Surgical restraints & $\mathbf{n}(\%)$ \\
\hline Comorbidities & $9(32.1)$ \\
Advanced disease & $8(28.6)$ \\
Lung impairment function & $6(21.4)$ \\
Anatomical constraints to surgery & $4(14.3)$ \\
Surgery refusal & $1(3.6)$ \\
\hline
\end{tabular}

with primary or secondary lung cancer were selected to RFA after an oncology multidisciplinary board decision. Impaired lung function, other comorbidities, anatomical restraints, advanced disease and patient refusal to have surgery were the main contraindications to surgical treatment as first choice (Table 1).

Before the procedure, a thorough clinical assessment was carried out, recent laboratory tests evaluated and imaging studies reviewed. Pulmonary function tests were not considered mandatory, as there are no constraints related to the forced expiratory volume in 1 second $\left(\mathrm{FEV}_{1}\right)$ or the diffusion capacity (DLCO). Antiplatelet and anticoagulant medication was previously discontinued. Chest CT was the imaging technique chosen to assess the lesion's size, shape, location and their relation to other structures, aspects of interest in the preliminary planning.

All patients provided written informed consent to the RFA procedure after a careful explanation of the technique and associated risks.

\section{Radiofrequency Technique}

Local anaesthesia with intradermal and subcutaneous lidocaine $(1 \%)$ was used at the needle insertion point and conscious sedation was achieved with intravenous midazolam and fentanyl. All patients were submitted to a pre-anaesthetic consultation and during the procedure were continuously monitored by an anaesthesiologist.

Each patient was specifically positioned over the CT table according to the predetermined needle tract, in order to provide the shortest and most direct path to the tumour, without crossing major thoracic structures. Amendments to the needle orientation were made by CT guidance. After the final adjustments, an umbrella-tip LeVeen radiofrequency (RF) electrode (Boston Scientific, Natick, Massachusetts, USA) with sphere diameter between 2 and $4 \mathrm{~cm}$ selected as appropriated for each lesion, and introduced, deep inside it, also under CT guidance (Fig.s 1 and 2).

The electrode was coupled to a generator RF 3000 (Boston Scientific) that exhibited temperature, power, impedance and time displays and was secured by pads placed on the anterolateral aspect of each thigh. Power setting was initially $40 \mathrm{~W}$, thereafter being administered in a stepwise manner pending a striking rise in impedance, which characterizes adequate thermocoagulation, and marked the end of the procedure. As criteria for safety margins we considered a 6-8 $\mathrm{mm}$ normal lung parenchyma tissue necrosis.

Multiplanar reconstructions or maximum intensity projections were supplementary obtained when there was doubt about sufficient coverage of the tumour by the electrodes or to reassess the relationship with neighbouring structures.

\section{Post-treatment and Follow-up Studies}

Spiral CT was performed immediately after the ablation for a preliminary assessment of results and detection of complications (Fig. 2). A high-density area at the treatment 


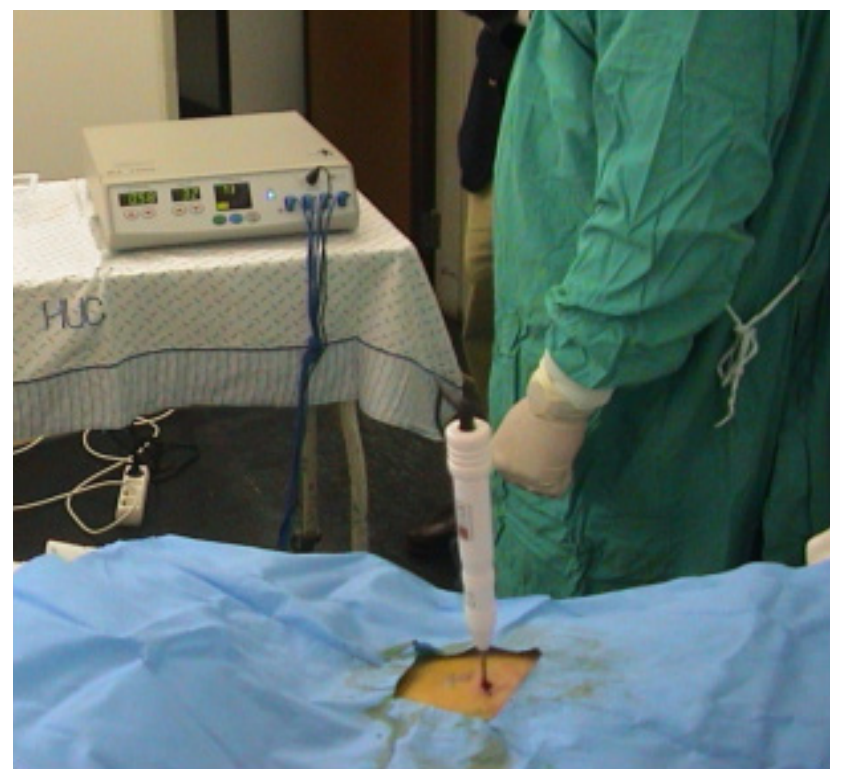

Figure 1 - Radiofrequency ablation treatment of a lung tumour. An umbrella-tip LeVeen RF electrode (Boston Scientific, Natick, Massachusetts, USA) is introduced deeply inside the tumour lesion, being coupled to a generator RF 3000 (Boston Scientific) that presents temperature, power, impedance and time displays.

site with a diameter equal to or greater than the initial tumour, surrounded by a rim of parenchymal ground-glass, resulting of inflammation and oedema induced by the procedure, and also non-enhanced after contrast administration was defined as successful treatment. All patients had a 2-hours postprocedure chest radiograph to assess for pneumothorax.

Follow-up included clinical examination at the Oncology Unit and routine CT scan plus positron emission tomography (PET) for 1 year. Frequency of local recurrence, disease progression and mortality were the primary end-points.

Increased enhancement after the intravenous administration of contrast material on chest CT at 1-2 months of follow-up compared to the pre-treatment baseline enhancement was recognized as residual or recurrent malignant disease. The same principle was considered for enduring 18-fludeoxyglucose (18-FDG) on PET uptake 6 months after ablation. On the other hand, necrosis, identified as a non-enhancing area larger than the ablated tumour, cavitation or cysts were considered as complete response to treatment.

\section{Statistical Analysis}

Data analysis was done by IBM SPSS Statistics ${ }^{\circledR}$ for Windows version 20.0. Follow-up was calculated from the date of treatment to the date of last follow-up. The patient characteristics and treatment success were reported using frequency and descriptive analyses. All analysis related to short- and long-term follow-up, including survival, local recurrence and disease progression calculations included all patients, except the one single case of death procedurerelated. Mortality rates were calculated and the KaplanMeier method applied to estimate survival. Univariate analysis (log rank) was carried out to determine the clinical and pathological factors affecting survival. The variables tested were: age, sex, size and position of the ablated lesion, primary tumour histology, Zubrod performance status, previous treatments, ablation-related complications, local recurrence or disease progression and comorbidities. $P$ value of $<0.05$ was considered statistically significant. Multivariate analysis was performed on all factors $(p<0.10)$ using the Cox proportional hazards regression model.

\section{RESULTS \\ Patient Population}

Patient and tumour characteristics are summarized in Table 2. A total of 28 patients, 22 men $(78.6 \%)$, with an overall mean (range) age of $62.0 \pm 17.0$ (6-81) years, underwent a single RFA session with only one electrode insertion used to treat each one of the lung tumours, 20 primary cancers $(71.4 \%)$ and 8 metastatic $(28.6 \%)$. The lesion's average (range) diameter size was $30.0 \pm 13.6$ (970) $\mathrm{mm}$ and their location was mainly at the lung periphery $(n=18 ; 64.3 \%)$. Only 2 patients $(7.1 \%)$ had not previously received any other treatment modality due to low pulmonary function, thus RFA being their first therapeutic option. All the remaining 26 patients $(92.9 \%)$ had formerly been submitted to combined or isolated cytostatic treatment, 3 of whom also underwent to lobectomy (10.7\%).
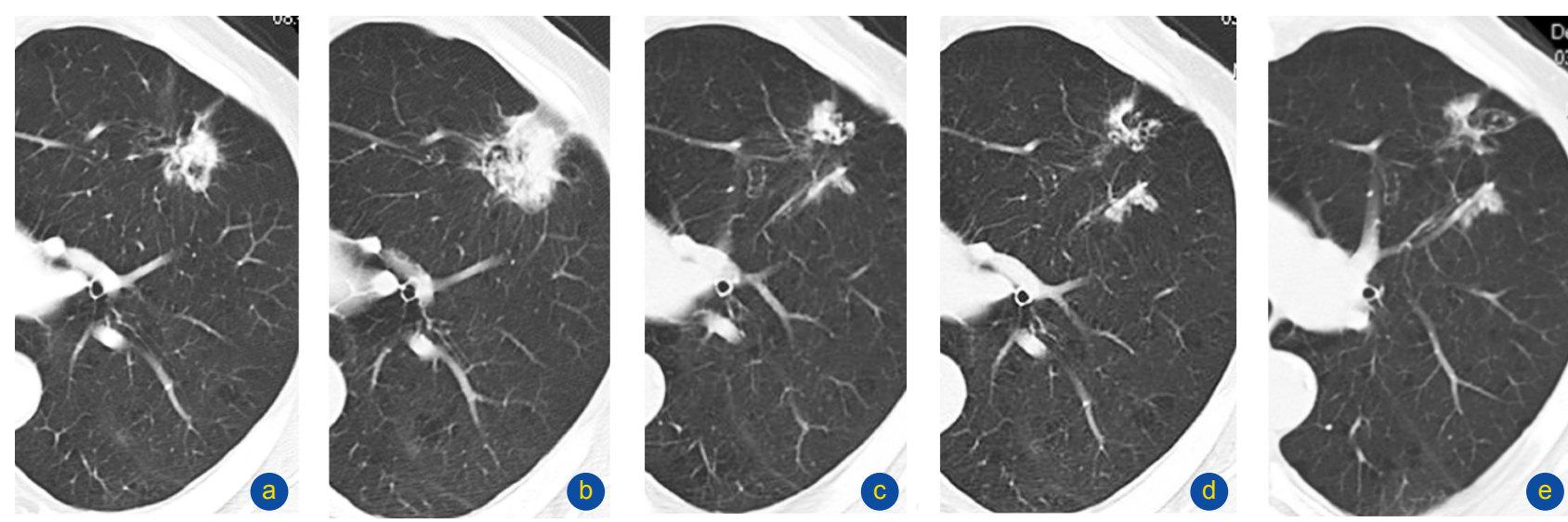

Figure 2 - Thoracic CT showing images of a nodular lesion diagnosed as a lung adenocarcinoma before radiofrequency ablation (a) and at $1,3,6$ and 12 months of follow-up (b, c, d and e, respectively). 
Table 2 - Frequency and Overall Survival by Demographic and Clinical Variables

\begin{tabular}{|c|c|c|c|}
\hline Patients Characteristics & n (\%) & $\begin{array}{l}\text { Median survival } \\
\text { (months) }\end{array}$ & $p$ value \\
\hline Patients, $\mathrm{n}$ & $27^{+}$ & 43.0 & \\
\hline $\begin{array}{l}\text { Sex } \\
\text { Male } \\
\text { Female }\end{array}$ & $\begin{array}{c}21(77.8) \\
6(22.2)\end{array}$ & $\begin{array}{l}97.0 \\
39.7\end{array}$ & NS \\
\hline $\begin{array}{l}\text { Age, yrs } \\
\text { Overall, mean } \pm \text { SD (range) } \\
<45 \\
45-60 \\
>60\end{array}$ & $\begin{array}{l}69 \pm 17(16-81) \\
3(11.1) \\
5(18.5) \\
19(70.4)\end{array}$ & $\begin{array}{l}38.6 \\
97.0 \\
31.6\end{array}$ & NS \\
\hline $\begin{array}{l}\text { Zubrod Performance Status* } \\
\text { Zubrod } 0 \\
\text { Zubrod } 1 \\
\text { Zubrod } 2\end{array}$ & $\begin{array}{l}3(15.0) \\
15(75.0) \\
2(10.0)\end{array}$ & $\begin{array}{l}31.6 \\
97.0 \\
14.3\end{array}$ & NS \\
\hline $\begin{array}{l}\text { Tumour Histology } \\
\text { NSCLC } \\
\text { SCLC } \\
\text { Pulmonary Metastasis }\end{array}$ & $\begin{array}{l}17(63.0) \\
3(11.1) \\
7(25.9)\end{array}$ & & NS \\
\hline $\begin{array}{l}\text { Tumour Position } \\
\text { Central } \\
\text { Peripheral }\end{array}$ & $\begin{array}{l}10(37.0) \\
17(63.0)\end{array}$ & $\begin{array}{l}43.0 \\
38.6\end{array}$ & NS \\
\hline $\begin{array}{l}\text { Target Lesion Size, } \mathrm{mm} \\
<20 \\
20-35 \\
>35\end{array}$ & $\begin{array}{l}7(25.9) \\
14(51.9) \\
6(22.2)\end{array}$ & $\begin{array}{c}46.1 \\
43.0 \\
9.7\end{array}$ & 0.003 \\
\hline $\begin{array}{l}\text { TNM 7th Classification Staging* } \\
\text { I } \\
\text { II } \\
\text { III } \\
\text { IV }\end{array}$ & $\begin{array}{l}7(25.0) \\
2(10.0) \\
8(40.0) \\
3(15.0)\end{array}$ & $\begin{array}{l}39.7 \\
10.0 \\
97.0 \\
31.6\end{array}$ & 0.011 \\
\hline $\begin{array}{l}\text { Pre-ablation treatments } \\
\text { No previous treatment } \\
\text { Chemotherapy } \\
\text { Radio-chemotherapy } \\
\text { Surgery and adjuvant radio-chemotherapy }\end{array}$ & $\begin{array}{c}2(7.4) \\
10(37.0) \\
12(44.4) \\
3(11.1)\end{array}$ & $\begin{array}{l}8.9 \\
31.6 \\
97.0 \\
38.6\end{array}$ & 0.006 \\
\hline $\begin{array}{l}\text { Immediate Ablation Outcome } \\
\text { Complete necrosis } \\
\text { Partial necrosis } \\
\text { Unsuccessful }\end{array}$ & $\begin{array}{l}20(74.1) \\
4(14.8) \\
3(11.1)\end{array}$ & $\begin{array}{l}31.6 \\
21.1 \\
14.1\end{array}$ & NS \\
\hline $\begin{array}{l}\text { Procedure-related complications } \\
\text { Major } \\
\text { Minor } \\
\text { No complication }\end{array}$ & $\begin{array}{l}3(11.1) \\
11(40.7) \\
13(40.1)\end{array}$ & $\begin{array}{l}7.4 \\
37.1 \\
71.6\end{array}$ & NS \\
\hline $\begin{array}{l}\text { Local recurrence } \\
\text { No } \\
\text { Yes }\end{array}$ & $\begin{array}{c}24(88.9) \\
3(11.1)\end{array}$ & $\begin{array}{l}43.0 \\
38.6\end{array}$ & NS \\
\hline $\begin{array}{l}\text { Disease progression } \\
\text { No } \\
\text { Yes }\end{array}$ & $\begin{array}{l}11(40.7) \\
16(59.3)\end{array}$ & $\begin{array}{l}- \\
-\end{array}$ & 0.001 \\
\hline $\begin{array}{l}\text { Comorbidities } \\
\text { Arterial Hypertension } \\
\text { No } \\
\text { Yes }\end{array}$ & $\begin{array}{l}20(74.1) \\
7(25.9)\end{array}$ & $\begin{array}{l}97.0 \\
31.6\end{array}$ & NS \\
\hline $\begin{array}{l}\text { Atrial Fibrillation } \\
\text { No } \\
\text { Yes }\end{array}$ & $\begin{aligned} 25 & (92.6) \\
2 & (7.4)\end{aligned}$ & $\begin{array}{l}31.6 \\
10.4\end{array}$ & NS \\
\hline $\begin{array}{l}\text { Ischemic myocardiopathy } \\
\text { No } \\
\text { Yes }\end{array}$ & $\begin{array}{c}24(88.9) \\
3(11.1)\end{array}$ & $\begin{array}{l}97.0 \\
43.0\end{array}$ & NS \\
\hline $\begin{array}{l}\text { Diabetes mellitus } \\
\text { No } \\
\text { Yes }\end{array}$ & $\begin{array}{l}21(78.8) \\
6(22.2)\end{array}$ & $\begin{array}{l}31.6 \\
39.2\end{array}$ & NS \\
\hline $\begin{array}{l}\text { Dyslipidaemia } \\
\text { No } \\
\text { Yes }\end{array}$ & $\begin{array}{l}22(81.5) \\
5(18.5)\end{array}$ & $\begin{array}{l}31.6 \\
24.5\end{array}$ & NS \\
\hline $\begin{array}{l}\text { Respiratory Insufficiency } \\
\text { No } \\
\text { Yes }\end{array}$ & $\begin{array}{l}24(88.9) \\
3(11.1)\end{array}$ & $\begin{array}{l}31.6 \\
7.4\end{array}$ & NS \\
\hline $\begin{array}{l}\text { Pulmonary Emphysema } \\
\text { No } \\
\text { Yes }\end{array}$ & $\begin{array}{l}21(78.8) \\
6(22.2)\end{array}$ & $\begin{array}{l}37.1 \\
10.4\end{array}$ & NS \\
\hline $\begin{array}{l}\text { Asthma } \\
\text { No } \\
\text { Yes }\end{array}$ & $\begin{array}{c}26(96.3) \\
1(3.7) \\
\end{array}$ & $\begin{array}{l}31.6 \\
71.6\end{array}$ & NS \\
\hline
\end{tabular}




\section{Complications}

Short-term complications were detected in 14 patients (50.0\%). Eleven patients experienced minor complications $(39.3 \%)$ and 3 patients had major complications $(10.7 \%)$. The most frequent complication was self-limiting pneumothorax (25.0\%), which occurred in 7 patients. Other minor complications included: one case of a small self-limited pleural effusion and three cases of mild bleeding successfully treated with aminocaproic acid, one slight hemoptoic sputum and two intraparenchymal haemorrhages. Major complications comprised isolated cases of pneumothorax, pleural effusion and subcutaneous emphysema that required chest tube drainage for complete resolution. Procedure-related mortality occurred in one patient three days after the procedure due to haemopneumothorax (3.5\%) despite immediate chest tube insertion. During a one-year follow-up, no long-term complications were observed.

\section{Efficacy}

Efficacy treatment analysis excluded the one single case of procedure-related mortality. Complete tumour necrosis was observed in 20 patients $(74.1 \%)$. In 4 patients the axial diameter did not increase, but there was a ground-glass opacity halo and non-enhancement, indicating a $14.8 \%$ rate of partial response to ablation. Treatment failure, defined as absence of all three criteria, occurred in 4 patients (14.8\%). At one-year follow-up, 16 patients $(59.3 \%)$ had disease progression and 3 patients (11.1\%) experienced local recurrence. Overall mortality during follow-up occurred in 13 patients $(48.1 \%)$ and all due to disease progression.

Overall survival analyses are discriminated in Table 2. Median overall survival was 43.0 months and median progression-free survival was 31.6 months.

There was no statistically significant difference in survival for age, sex, primary tumour histology, tumour location, Zubrob performance status and ablation treatment success.

The tumour diameter correlated directly with overall survival. When taking into account different categories of tumour dimension, overall survival was substantially longer for lesions equal to or smaller than $35 \mathrm{~mm}$ in diameter compared to diameters greater than $35 \mathrm{~mm}(p=0.003)$ by an average difference of 32 months.

TNM staging was associated with statistically significant differences in survival $(p=0.011)$. Median overall survival for primary lung cancer was higher for those in stage III, 97.0 months, and smaller for those in stage II, 10.0 months. On the other hand, stages I and IV were associated to intermediate survivals, 39.7 months and 31.6 months, respectively.

Ablation-related complications, particularly major ones, and previously diagnosed chronic obstructive pulmonary disease were associated to lower survival rated but this result had no statistical significance.

Patients with primary lung cancer that had had CTX prior to the ablation procedure had a median overall survival of
89.7 months while those that did not had worst results with a survival of 8.6 months $(p=0.003)$. Pre-procedure CTX, with or without other simultaneous treatments, was the most important predictor of survival. When associated to concomitant radiotherapy, the overall survival increased to a median of 97.0 months. Absence of preceding treatments had the worst overall survival rates of 8.9 months $(p=0.006)$ Local recurrence had no interference in survival whereas disease progression accounted for a meaningful decrease in overall survival $(p=0.001)$. Multivariate analysis showed that having been submitted to any kind of previous treatment was related to a 4.5 -fold increase in overall survival.

\section{DISCUSSION}

In this study, percutaneous RFA proved to be a minimally invasive procedure with confirmed efficacy in the treatment of isolated lung cancerous lesions, either primary or secondary, tumour lung lesions in highly selected patients. It is a feasible alternative either when surgery is not possible or is refused, and as a complementary role in treatment for lung cancer.

Imaging follow-up is vital to certificate treatment success and exclude the presence of residual tumour after ablation. Contrast-enhanced CT scan appeared to be a reliable way to immediately evaluate treatment results and certify complete tumour necrosis by measuring the post-treatment size increase at the tumour site, recognizing ground-glass opacity halo and discarding enhancement after contrast administration. All three criteria were identified in 21 patients, which were consistent with complete necrosis and correlated to a success treatment rate of $75.0 \%$. Possible explanations for the $25.0 \%$ rate of incomplete necrosis and treatment failure are some degree of pre-existing tumour necrosis and raised heat 'sink effect', both associated to higher energy requirements, ${ }^{30}$ and inaccurate electrode placement. In one case, it was not possible to assess immediate treatment response due to major complications that led to the patient's death.

In the current study, there was a low rate of local recurrence, which corroborates the ablation high effectiveness. However, mean (range) follow-up during $24.0 \pm 20.7$ months only, may have induced a slight underestimation, since it has been stated that residual tumour may recur up to 2 years after RFA.

Overall procedure-related complications incidence $(55.2 \%)$ was significantly higher than that reported in previous studies ${ }^{31}$ although the overwhelming majority were mild and self-limited, and the severe ones led to only one fatal outcome. Procedure-related complications showed no correlation with overall survival in univariate analysis. This excessive rate of complications might be interrelated to a high prevalence of pulmonary comorbidities, such as asthma, COPD and emphysema. In fact, the patient who died from the procedure had severe airway obstruction due to extensive centrilobular and bullous emphysema, which may call into question if pulmonary function is not after all an important contraindication to consider for this type of 
procedure. Also, in almost half of those that experienced complications $(43.8 \%)$ there was no anatomical cleavage plane with some important structures such as the pleura, blood vessels and the thoracic wall.

Disease stages, according to TNM Classification of primary malignant lung cancer ( $7^{\text {th }}$ edition), correlated meaningfully with overall survival $(p=0.011)$. Stage III was associated with the best overall survival while stage IV presented intermediate results, suggesting that radiofrequency ablation may be effectively executed in patients with advance disease. However, the overall small sample size and the low number of patients in some of the disease stages limit this conclusion.

The lack of association between the lesion location and its histological type indicates that RFA may be employed in several types of central or peripheral lung tumours with similar results.

Consistent with previous reports, one important prognostic factor was the target lesion axial diameter, with superior overall survival for tumours smaller than 35 $\mathrm{mm}$, although some studies report successful treatment in tumours up to $50 \mathrm{~mm} .^{24,32}$

There were longer overall survival rates among patients who underwent former systemic CTX, radio-CTX or surgery and adjuvant radio-CTX, indicating that RFA may be promisingly coupled with other treatment modalities, even lung resection. Only 5 of these patients had advanced disease. Concurrently, the mean lesion's diameter was less than $30 \mathrm{~mm}$, which may help explain the survival rates. Only 2 patients had no other kind of treatment prior to the ablation procedure, and both had lower overall survival rates. These patients presented particularly large primary lung tumour lesions with 40 and $70 \mathrm{~mm}$ in axial diameter respectively (average $55 \mathrm{~mm}$ ), when compared to the average $30 \mathrm{~mm}$ diameter in the by-other modalities treated group and as previously reported, size is thus a major feature affecting survival. However, these preliminary conclusions are still waiting for future validation in prospective trials.

In the follow-up analysis, disease progression occurred in more than half of the patients, being the cause of death in all the 13 deceased patients, corresponding to a diseaserelated mortality of $46.4 \%$. However, local recurrence occurred in only 2 patients, which suggests that RFA may be a highly effective procedure in controlling lung tumour growth and providing its successful destruction.

Our study has several limitations. The first is the small sample size, which constraint the strength of our conclusions. The second, and probably the most important limitation worth noting, is that our study population is highly heterogeneous. In fact, we included patients with different histological primary and secondary tumours, including adenocarcinoma, squamous cell carcinoma and neuroendocrine cancer, and also patients submitted to diverse treatment schemes and modalities. However, most of the studies previously published have also dealt with heterogeneous and small populations. . $8,20,21,28,33^{\text {The most }}$ obvious explanation for this is that RFA is still not a fully implemented treatment for lung cancer, making it difficult to enrol in a study a significant number of patients with similar characteristics. In addition, the most important criteria for RFA is contraindication for surgery, which encompasses a vast group of patients. Nonetheless, assembling a series of patients submitted to distinct treatment modalities allowed us to observe that RFA combined with other treatment modalities may have an excellent synergistic effect, improving lung tumours outcomes, especially in patients unfit for surgery or that refuse surgical treatment. Furthermore, it may be used to treat recurrent lesions after an early surgical approach, even more so when we consider that repeated lung surgeries pose significant procedurerelated morbidity and modest results. ${ }^{23}$

As for the strengths of our study, it is to stress the fact of assembling so much clinical data for each patient, the long-term 2-year follow-up when compared to shorter-term reports and the meticulous multivariate analysis that was performed, testing the main variables affecting survival.

\section{CONCLUSION}

In this study, CT-guided percutaneous RFA is a minimally invasive procedure, associated to low morbidity and mortality rates and proven efficacy in the treatment of primary or metastatic small tumour lung lesions, especially when combined with other lung cancer treatment modalities. Advantages of RFA include the possibility of performing multiple sessions, even in patients with limited pulmonary reserve, as well as repeating the treatment with a relatively low risk of complications. However, further studies are needed to empower our findings, specifically studies with large sample sizes.

\section{CONFLICTS OF INTEREST}

The authors declare that there are no conflicts of interest.

\section{FUNDING SOURCES}

No subsidies or grants contributed to this work.

\section{REFERENCES}

1. Parkin DM, Bray F, Ferlay J, Pisani P. Global cancer statistics, 2002. CA Cancer J Clin. 2005;55:74-108.

2. Jemal A, Siegel R, Ward E, Hao Y, Xu J, Murray T, et al. Cancer statistics, 2008. CA Cancer J Clin. 2008;58:71-96.

3. Hess KR, Varadhachary GR, Taylor SH, Wei W, Raber MN, Lenzi R, et al. Metastatic patterns in adenocarcinoma. Cancer. 2006;106:1624-33.

4. Scott WJ, Howington J, Feigenberg S, Movsas B, Pisters K. Treatment of non-small cell lung cancer stage I and stage II: ACCP evidence-based clinical practice guidelines. $2^{\text {nd }}$ edition. Chest. 2007;132:234S-42.

5. Onishi H, Shirato H, Nagata Y, Hiraoka M, Fujino M, Gomi K, et al. Stereotactic body radiotherapy (SBRT) for operable stage I non-smallcell lung cancer: can SBRT be comparable to surgery? Int J Radiat Oncol Biol Phys. 2011;81:1352-8.

6. Baba F, Shibamoto $Y$, Ogino $H$, Murata $R$, Sugie $C$, Iwata $H$, et al. Clinical outcomes of stereotactic body radiotherapy for stage I non-small cell lung cancer using different doses depending on tumor size. Radiat 
Oncol. 2010:5:81.

7. Grills IS, Mangona VS, Welsh R, Chmielewski G, McInerney E, Martin S, et al. Outcomes after stereotactic lung radiotherapy or wedge resection for stage I non-small-cell lung cancer. J Clin Oncol. 2010;28:928-35.

8. Dupuy DE. Image-guided thermal ablation of lung malignancies. Radiology. 2011;260:633-55.

9. Pereira PL, Masala S, Salvatore M. Standards of practice: guidelines for thermal ablation of primary and secondary lung tumors. Cardiovasc Intervent Radiol. 2012;35:247-54.

10. Mayo SC, Pawlik TM. Thermal ablative therapies for secondary hepatic malignancies. Cancer J. 2010;16:111-7.

11. Lencioni R, Crocetti L. Image-guided ablation for hepatocellular carcinoma. Recent Results Cancer Res. 2013;190:181-94.

12. Tanabe KK, Curley SA, Dodd GD, Siperstein AE, Goldberg SN. Radiofrequency ablation: the experts weigh in. Cancer. 2004;100:64150 .

13. Rosenthal DI, Hornicek FJ, Torriani M, Gebhardt MC, Mankin HJ. Osteoid osteoma: percutaneous treatment with radiofrequency energy. Radiology. 2003;229:171-5

14. Gervais DA, McGovern FJ, Arellano RS, McDougal WS, Mueller PR. Renal cell carcinoma: clinical experience and technical success with radio-frequency ablation of 42 tumors. Radiology. 2003;226:417-24.

15. Dupuy DE, Zagoria RJ, Akerley W, Mayo-Smith WW, Kavanagh P V, Safran $\mathrm{H}$. Percutaneous radiofrequency ablation of malignancies in the lung. AJR Am J Roentgenol. 2000;174:57-9.

16. Nguyen CL, Scott WJ, Young NA, Rader T, Giles LR, Goldberg M. Radiofrequency ablation of primary lung cancer: results from an ablate and resect pilot study. Chest. 2005;128:3507-11.

17. De Baère T, Palussière $J$, Aupérin $A$, Hakime $A$, Abdel-Rehim $M$, Kind $M$, et al. Midterm local efficacy and survival after radiofrequency ablation of lung tumors with minimum follow-up of 1 year: prospective evaluation. Radiology. 2006;240:587-96.

18. Rossi S, Dore R, Cascina A, Vespro V, Garbagnati F, Rosa L, et al. Percutaneous computed tomography-guided radiofrequency thermal ablation of small unresectable lung tumours. Eur Respir J. 2006;27:55663.

19. Sano Y, Kanazawa S, Gobara H, Mukai T, Hiraki T, Hase S, et al. Feasibility of percutaneous radiofrequency ablation for intrathoracic malignancies: a large single-center experience. Cancer. 2007;109:1397-405.

20. Simon CJ, Dupuy DE, DiPetrillo TA, Safran HP, Grieco CA, $\mathrm{Ng}$ T, et al. Pulmonary radiofrequency ablation: long-term safety and efficacy in 153 patients. Radiology. 2007;243:268-75.

21. Galbis-Caravajal JM, Pallardó-Calatayud Y, Revert-Ventura A, SalesBadía JG, Esturi-Navarro R, Cuenca-Torres M. Computed tomography- guided radiofrequency ablation of malignant lung lesions: early experience. Arch Bronconeumol. 2008;44:364-70.

22. Rose SC. Radiofrequency ablation of pulmonary malignancies. Semin Respir Crit Care Med. 2008;29:361-83.

23. Chua TC, Sarkar A, Saxena A, Glenn D, Zhao J, Morris DL. Long-term outcome of image-guided percutaneous radiofrequency ablation of lung metastases: an open-labeled prospective trial of 148 patients. Ann Oncol. 2010;21:2017-22.

24. Baisi A, De Simone M, Raveglia F, Cioffi U. Thermal ablation in the treatment of lung cancer: present and future. Eur J Cardiothorac Surg. 2013;43:683-6.

25. Nahum Goldberg S, Dupuy DE. Image-guided radiofrequency tumor ablation: challenges and opportunities--part I. J Vasc Interv Radiol. 2001;12:1021-32.

26. Oshima F, Yamakado K, Akeboshi M, Takaki H, Nakatsuka A, Makita $M$, et al. Lung radiofrequency ablation with and without bronchia occlusion: experimental study in porcine lungs. J Vasc Interv Radiol. 2004;15:1451-6.

27. Ahmed M, Liu Z, Afzal KS, Weeks D, Lobo SM, Kruskal JB, et al Radiofrequency ablation: effect of surrounding tissue composition on coagulation necrosis in a canine tumor model. Radiology. 2004;230:7617.

28. Dupuy DE, DiPetrillo T, Gandhi S, Ready N, Ng T, Donat W, et al. Radiofrequency ablation followed by conventional radiotherapy for medically inoperable stage I non-small cell lung cancer. Chest. 2006;129:738-45

29. Pennathur A, Luketich JD, Abbas G, Chen M, Fernando HC, Gooding $W E$, et al. Radiofrequency ablation for the treatment of stage I nonsmall cell lung cancer in high-risk patients. J Thorac Cardiovasc Surg 2007;134:857-64.

30. Goldberg SN, Hahn PF, Tanabe KK, Mueller PR, Schima W, Athanasoulis $\mathrm{CA}$, et al. Percutaneous radiofrequency tissue ablation: does perfusion-mediated tissue cooling limit coagulation necrosis? J Vasc Interv Radiol. 1998:9:101-11.

31. Zhu JC, Yan TD, Morris DL. A systematic review of radiofrequency ablation for lung tumors. Ann Surg Oncol. 2008;15:1765-74.

32. Pereira PL, Masala S, Salvatore M. Standards of practice: guidelines for thermal ablation of primary and secondary lung tumors. Cardiovasc Intervent Radiol. 2012;35:247-54.

33. Hiraki T, Sakurai J, Tsuda T, Gobara H, Sano Y, Mukai T, et al. Risk factors for local progression after percutaneous radiofrequency ablation of lung tumors: evaluation based on a preliminary review of 342 tumors. Cancer. 2006;107:2873-80. 


\section{Efficacy and Safety of Percutaneous Radiofrequency Thermal Ablation in the Treatment of Lung Cancer Lesions}

Acta Med Port 2015:28:63-69

Publicado pela Acta Médica Portuguesa, a Revista Científica da Ordem dos Médicos

Av. Almirante Gago Coutinho, 151

1749-084 Lisboa, Portugal.

Tel: +351218428215

E-mail: submissao@actamedicaportuguesa.com

www.actamedicaportuguesa.com

ISSN:0870-399X | e-ISSN: 1646-0758

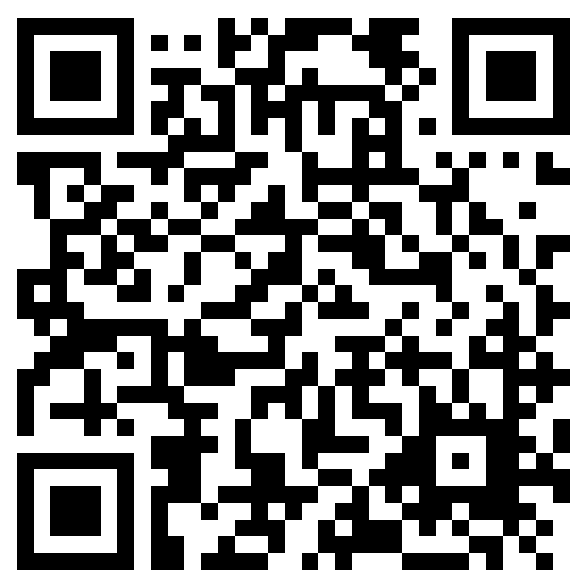

